\title{
Simultaneous Estimation of Atenolol and Chlorthalidone as Bulk and In Tablet Dosage Form Using Uv- Spectrophotometry
}

\author{
Akiful Haque.M, Nivedita.G*, Prashanth Kumar.K, Pradeep Kumar.T, Hasan \\ Amrohi.S and Prakash.V.Diwan. \\ School of Pharmacy, Anurag group of Institutions, Ghatkesar(M), Hyderabad.
}

\begin{abstract}
A simple, accurate, precise, economical and reproducible UV Spectrophotometric method has been developed for the simultaneous estimation of Atenolol and Chlorthalidone in bulk and in combined tablet dosage form. The stock solutions were prepared in methanol followed by further required dilutions with methanol. The absorbance maxima of Atenolol and Chlorthalidone were found to be $225 \mathrm{~nm} \& 284 \mathrm{~nm}$ respectively. Beers law obeyed the concentration range of atenolol is $10 \mu \mathrm{g} \mathrm{mL} L^{-1}$ to $60 \mu \mathrm{g} \mathrm{mL} L^{-1}$ \&

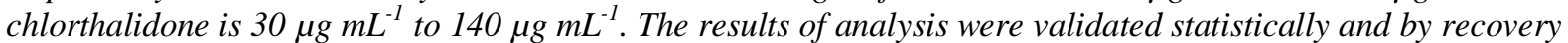
studies. The \% RSD for the recovery study was less than 2. The proposed method can be effectively applied for the simultaneous estimation of these two drugs in bulk \& combined dosage forms.
\end{abstract}

Keywords: UV spectrophotometric method; atenolol; chlorthalidone and simultaneous estimation.

\section{Introduction:}

Atenolol chemically, 2-[4-\{(2RS)-2-hydroxy-3-[(1-methylethyl)amino]propoxy\}phenyl] acetamide (fig. 1) is a selective $\beta_{1}$ receptor antagonist, a drug belonging to the group of beta blockers, a class of drugs used primarily in cardiovascular diseases. The chemical works by slowing down the heart and reducing its workload. Atenolol does not pass through the blood-brain barrier thus avoiding various central nervous system side effects. ${ }^{[1]}$ Atenolol is primarily used for hypertension, anginapectoris \&myocardial infarction. I mainly act by inhibition of renin release and angiotensin-II (AT-II) and aldosterone production. Chlorthalidone chemically 2chloro-5-(1-hydroxyl-3-oxo-2,3-dihydro-1H-isoindol-1-yl) benzene-1-sulfonamide (fig. 2) is widely used in antihypertensive pharmaceutical preparations, reduces active sodium reabsorption and peripheral vascular resistance. Chlortalidone is a diuretic drug used to treat hypertension. It is described as a thiazide diuretic. Compared with other medications of the thiazide class, chlorthalidone has the longest duration of action but a similar diuretic effect at maximal therapeutic doses. It is often used in the management of hypertension and edema.

Literature survey reveals that there are several analytical methods for the estimation of atenolol and chlorthalidone individually or in combination with other drugs. Although the combination use of atenolol \& chlorthalidone is continuously increasing, there is no UV method for the determination of these drugs in combined dosage form. Hence the aim of my study is to develop and validate a simple, precise, accurate, selective UV method for the estimation of atenolol and chlorthalidone in combined dosage form.

\section{Methods And Materials:}

Materials:

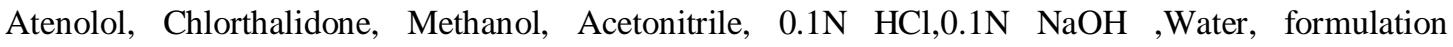
TENOCLOR (Atenolol 25mg, Chlorthalidone 12.5mg), Shimadzu UV-Visible spectrophotometer (model UV1800) with matched quartz cells.

Selection of solvent and wavelength $(\lambda$ max):

The absorbance of the both drugs i.e. atenolol and chlorthalidone was found to be maximum in methanol solvent compared to other solvents, the $\lambda$ max of atenolol and chlorhalidone was fixed as $225 \mathrm{~nm}$ and $284 \mathrm{~nm}$ respectively.

\section{Preparation of Atenolol Stock Solution:}

Standard atenolol stock solution was prepared by dissolving $100 \mathrm{mg}$ of drug in methanol and volume make up to $100 \mathrm{ml}$ with methanol to get concentration about of $1 \mathrm{mg} / \mathrm{ml}\left(1000 \mu \mathrm{g} \mathrm{mL} \mathrm{L}^{-1}\right.$ stock solution). From stock solution take $1 \mathrm{ml}$ of this solution was taken and diluted to $10 \mathrm{ml}$ with methanol to get final concentration of $100 \mu \mathrm{g} \mathrm{mL} \mathrm{L}^{-1}$.

Preparation of Clorthalidone stock solution:

Standard chlorthalidone stock solutions were prepared by dissolving $100 \mathrm{mg}$ drug in methanol and volume make up to $100 \mathrm{ml}$ with methanol to get concentration of $1 \mathrm{mg} / \mathrm{ml}$ solutions. $\left(1000 \mu \mathrm{g} \mathrm{mL}^{-1}\right)$. From stock 
solution take $1 \mathrm{ml}$ of this solution was taken and diluted to $10 \mathrm{ml}$ with methanol to get final concentration of $100 \mu \mathrm{g} \mathrm{mL}{ }^{-1}$.

Preparation of Linearity curve:

To construct Beer's law plot for atenolol and chlorthalidone different aliquots of atenolol (1-6ml) with different concentrations $\left(10,20,30,40,50\right.$ and $\left.60 \mu \mathrm{g} \mathrm{m}^{-1}\right)$ and chlorthalidone $(3-14 \mathrm{ml})$ with different concentrations $\left(30,40,50,60,70,80,90,100,110,120,130\right.$ and $\left.140 \mu \mathrm{g} \mathrm{mL}^{-1}\right)$ were prepared by serial dilutions with methanol. Mixed standard solutions were prepared from working standard solutions of the two drugs. Then absorbance of the solutions was measured at $225 \mathrm{~nm}$ for atenolol and $284 \mathrm{~nm}$ for chlorthalidone, respectively. Both these drugs obeyed linearity individually and in mixture with the concentration range of $10-60 \mu \mathrm{gL}^{-1}$ for atenolol and $30-140 \mu \mathrm{g} \mathrm{mL}^{-1}$ for chlorthalidone.

Preparation of Test Solutions and Estimation of atenolol and chlorthalidone in Tablet formulations:

For analysis of commercial formulations of tablets, 10 tablets were weighed, powdered and accurately weighed the equivalent to $25 \mathrm{mg}$ of atenolol and $12.5 \mathrm{mg}$ of chlorthalidone, which was transferred into $100 \mathrm{ml}$ volumetric flask and in methanol and make up to $100 \mathrm{ml}$ with methanol, filtered and further diluted with methanol to get the concentrations within the linearity range of respective drugs and measured the absorbances at $225 \mathrm{~nm}$ for atenolol and $284 \mathrm{~nm}$ for chlorthalidone fig. 4, respectively. Then the amount of drug present in the formulations was calculated using calibration curve. The results were shown in table-5.

Recovery studies:

The recovery studies were carried out at three different levels i.e. 50\%, 100\% and $150 \%$ level. To ensure the reliability of the above method, recovery studies were carried out by mixing a known quantity of standard drug with the pre analysed sample formulation and the contents were reanalyzed by the proposed method. The percentage recovery was found and shown in table- 2 .

\section{Results And Discussion:}

From the optical characteristics of the proposed method, it was found that the drug obeys linearity within the concentration range of 10-60 $\mu \mathrm{g} \mathrm{mL}$ for Atenolol and 30-140 $\mu \mathrm{g} \mathrm{mL}^{-1}$ for Chlorthalidone. From the results it was found that the \% RSD is less than $2 \%$ which indicates that the method has good reproducibility. From the results shown in accuracy table- 2 it was found that the percent recovery values of pure drug from the preanalysed solutions of formulations were in between $98.3 \%-100.16 \%$, which indicates that the method is accurate and which reveals that commonly used excipients and additives present in the pharmaceutical formulations did not interfere in the proposed method. The proposed method was simple, sensitive and reliable with good precision and accuracy. The proposed method is specific while estimating the commercial formulations without interference of excipients and other additives. Hence, this method can be used for the routine determination of Atenolol and Chlorthalidone in bulk samples and pharmaceutical formulations.

\section{Conclusion:}

A convenient and rapid UV method has been developed for simultaneous estimation of Atenolol and Chlorthalidone in available dosage form. The assay provides a linear response across a wide range of concentrations. Low intra-day and interday \% RSD coupled with excellent recoveries. Hence, this method can be easily and conveniently adopted for routine analysis of Atenolol and Chlorthalidone in pure form and its dosage forms.

\section{Acknowledgement:}

I am very much thankful School of pharmacy, Anurag group of Institutions, Hyderabad, for giving permission to carry out my research work. I am very much thank full to Principal Dr.Prakash.V.Diwan, and Assistant Professor M. Akiful Haque, for his guidance, kind help and constant encouragement at every step during the progress of my work .

[1]. http://www.drugbank.ca/drugs/DB00335

\section{References:}

[2]. Agon, P., Goethals, P., Van Haver, D. and Kaufman, J.M.: J. Pharm. Pharmacol., 43(8): 597-600 (1991).

[3]. http://www.drugbank.ca/drugs/DB00310

[4]. http://en.wikipedia.org/wiki/Chlorthalidone

[5]. Permender Rathee., Sushila Rathee., Shyama Thakur. and Vikash Kumar.: International Journal of Chem. Tech. Research CODEN (USA)., 2: 62-68 (2010).

[6]. Vetushi, C. and Ragno, G.: International Journal of Pharmaceutics., 65: 177-181 (1990).

[7]. Salvador, C.S. and Luz, E.: J. Chromatog. Sci., 690: 195-202 (1997).

[8]. El-Gindy., Alaa Sallam., Shehab. and Abdel Salam.: Journal of Separation Science., 31(4): 677-682 (2008).

[9]. Bilal, Y.: FABAD J. Pharm. Sci., 33: 119-129 (2008).

[10]. De croo, F., Van Den Bossche, W. and De Moerloose.: Journal of Chromatography A., 325: $395-411$ (1985).

[11]. Kavitha, J. and Muralidharan, S.: Internal Journal of Chem. Tech Research CODEN (USA)., 2: 880-884 (2010).

[12]. Pankaj Kumara., Shubhanjali Shukla., Ashok Laxman Rao, G. and Subudhi, B.B.: Der Pharma Chemica., 3(2): 13-21 (2011). 


\begin{tabular}{|c|c|c|}
\hline & Atenolol & Chlorthalidone \\
\hline Linearity $\mu \mathrm{g} \mathrm{mL}^{-1}$ & $10-60$ & $30-140$ \\
\hline $\begin{array}{c}\text { Correlation coefficient } \\
(\mathrm{r})\end{array}$ & 0.999 & 0.998 \\
\hline
\end{tabular}

Table No: 2 Recovery studies

\begin{tabular}{|c|c|c|c|c|c|}
\hline Drug & $\begin{array}{c}\% \\
\text { Recovery }\end{array}$ & $\begin{array}{c}\text { Amount added } \\
\mu \mathrm{g} \mathrm{mL}^{-1}\end{array}$ & $\begin{array}{l}\text { Amount } \\
\text { recovered } \\
\mu \mathrm{g} \mathrm{mL}\end{array}$ & $\%$ Recovery & $\% * \mathrm{RSD}$ \\
\hline \multirow{3}{*}{ Atenolol } & 50 & 12.5 & 12.42 & 99.36 & 0.342 \\
\hline & 100 & 25 & 24.85 & 99.4 & 0.145 \\
\hline & 150 & 37.5 & 37.47 & 99.92 & 0.426 \\
\hline \multirow{3}{*}{ Chlorthalidone } & 50 & 6.25 & 6.39 & 98.3 & 0.263 \\
\hline & 100 & 12.5 & 12.52 & 100.16 & 0.521 \\
\hline & 150 & 18.75 & 18.43 & 99.62 & 0.336 \\
\hline
\end{tabular}

$*=$ three estimations

Table No: 3 Precision studies

\begin{tabular}{|c|c|c|c|}
\hline \multirow{2}{*}{ Drug } & \multirow{2}{*}{$\begin{array}{c}\text { Concentration } \\
\mu \mathrm{g} \mathrm{mL} \mathrm{mL}^{-1}\end{array}$} & $\begin{array}{c}\text { Intra-day Precision } \\
(\mathbf{n}=\mathbf{3})\end{array}$ & $\begin{array}{c}\text { Inter-day Precision } \\
(\mathrm{n}=\mathbf{3})\end{array}$ \\
\hline & & \% RSD & $\%$ RSD \\
\hline Atenolol & 50 & 1.01 & 0.38 \\
\hline Chlorthalidone & 40 & 0.57 & 0.36 \\
\hline
\end{tabular}

Table No: 4 LOD and LOQ

\begin{tabular}{|c|c|c|}
\hline PARAMETERS & ATENOLOL & CHLORTHALIDONE \\
\hline $\begin{array}{c}\text { Limit of detection } \\
\left(\text { LOD) } \mu \mathrm{g} \mathrm{mL}^{-1}\right.\end{array}$ & 4 & 10 \\
\hline $\begin{array}{c}\text { Limit of } \\
\text { quantification } \\
\text { (LOQ) } \mu \mathrm{g} \mathrm{mL}^{-1}\end{array}$ & 10 & 30 \\
\hline
\end{tabular}

Table No: 5 Analysis of formulation

\begin{tabular}{|c|c|c|c|c|}
\hline Drug name & $\begin{array}{c}\text { Amount } \\
\text { labeled } \\
\text { (mg/tablet) }\end{array}$ & $\begin{array}{c}\text { Amount } \\
\text { estimated } \\
\text { (mg/tablet) }\end{array}$ & $\begin{array}{c}\text { \% Label } \\
\text { claim }\end{array}$ & $\%$ *RSD \\
\hline Atenolol & $25 \mathrm{mg}$ & 24.42 & 97.68 & 0.365 \\
\hline Chlorthalidone & $12.5 \mathrm{mg}$ & 12.19 & 97.52 & 0.524 \\
\hline
\end{tabular}

*= three estimations 
Table No: 6 Summary of validation parameters for proposed methods

\begin{tabular}{|c|c|c|}
\hline Parameters & Atenolol & Chlorthalidone \\
\hline Linearity & $10-60 \mu \mathrm{g} \mathrm{mL}^{-1}$ & $30-140 \mu \mathrm{g} \mathrm{mL}^{-1}$ \\
\hline $\begin{array}{l}\text { Linear regression } \\
\text { Intercept (c) }\end{array}$ & 0.032 & 0.004 \\
\hline Slope $(\mathrm{m})$ & 0.032 & 0.005 \\
\hline $\begin{array}{l}\text { Correlation } \\
\text { Coefficient }\end{array}$ & 0.999 & 0.998 \\
\hline $\begin{array}{l}\text { Limit of Detection } \\
\text { (LOD) }\end{array}$ & $4 \mu \mathrm{g} \mathrm{mL} L^{-1}$ & $10 \mu \mathrm{g} \mathrm{mL}^{-1}$ \\
\hline $\begin{array}{c}\text { Limit of } \\
\text { Quantification (LOQ) }\end{array}$ & $10 \mu \mathrm{g} \mathrm{mL}^{-1}$ & $30 \mu \mathrm{g} \mathrm{mL}^{-1}$ \\
\hline $\begin{array}{l}\text { Precision }(\% \mathrm{RSD}) \\
\text { Intraday }(\mathrm{n}=3)\end{array}$ & 1.01 & 0.57 \\
\hline Interday(n=3) & 0.38 & 0.36 \\
\hline
\end{tabular}

Fig. 1: Atenolol<smiles>CC(C)NCC(O)COc1ccc(CC(N)=O)cc1</smiles>

Fig. 2: Chlorthalidone<smiles>NS(=O)(=O)c1cc(NC(=O)c2ccccc2Cl)ccc1Cl</smiles>

Fig. 3: Overlain spectrun of standard Atenolol and Chlorthalidone

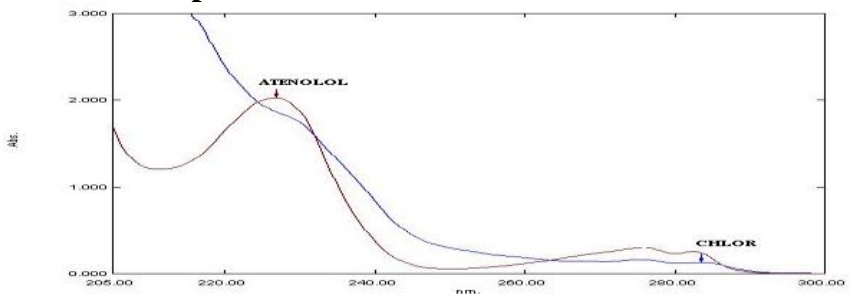

Fig.4:SpectraofAtenololand Chlorthalidone formulation

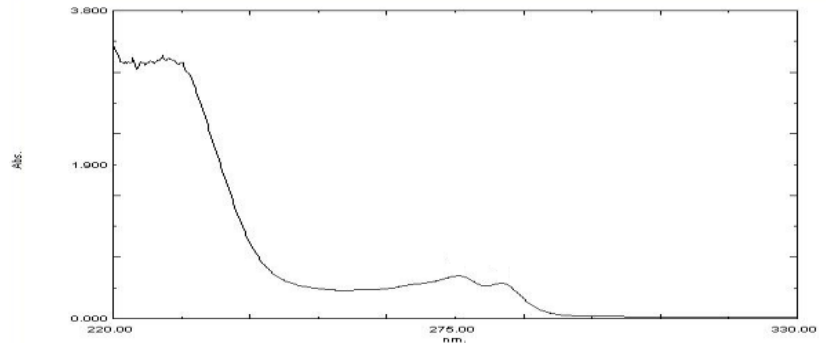

